\title{
FAKTOR-FAKTOR YANG BERPENGARUH TERHADAP STATUS GIZI OBESITAS ORANG DEWASA DI KOTA DEPOK, TAHUN 2007 Rahmawati ${ }^{1}$ dan Sudikno ${ }^{2}$ \\ 'Dinas Kesehatan Kota Depok \\ ${ }^{2}$ Pusat Penelitian dan Pengembangan Gizi dan Makanan, Depkes RI
}

\section{ABSTRACT \\ RISK FACTORS OF ADULT OBESITY IN DEPOK, WEST JAVA, IN 2007}

There has been eating habit changes in big cities from consuming healthy food containing complex carbohydrate, and high fiber to junk food containing a lot of protein, fat, sugar, and salt but little fiber and lack of physical activities will increase obesity. This study is an advance analysis of the risk factors of adult obesity and their characteristics in Depok. A cross-sectional study was conducted to collect data from 366 samples, 176 men and 190 women aged 18-55 years old. The samples were selected using rapid assessment survey methodology. Percentage of adult obesity status (18-55 years old) is 16.4 percent, which is higher than the result of a study conducted in $2004(12.5 \%)$. Percentage of women adult obesity status is higher than men. The women also have the risks of becoming obese 2.274 times higher than men. Percentage of adult obesity is different across age group $(p=0.044)$. The study showed that consuming deep fried food affected obesity status $(p=0.010)$. Respondents who often consumed deep fried food had the risks of being obese 2.337 times higher than those who rarely did that. In addition, it was found that respondents' favorite food (deep fried food, fatty food, and food containing a lot of sugar) affected their obesity status $(p<0.05)$. The analysis found the risks factors for adult obesity include age, sex, habits of consuming deep fried food, and favorite food (deep fried food, fatty food, and food containing a lot of sugar).

Keywords: adult, obesity, risk factors

\section{PENDAHULUAN}

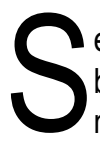
ebagaimana

dengan negara berkembang lainnya, pembangunan nasional yang dilaksanakan di Indonesia dalam semua aspek kehidupan telah meningkatkan taraf hidup dan umur harapan hidup. Keberhasilan pembangunan khususnya dalam bidang kesehatan dan gizi telah dapat menurunkan penyakit infeksi dan kekurangan gizi di beberapa daerah. Namun sebagai hasil samping dari keberhasilan pembangunan nasional, Indonesia mengalami era transisi masyarakat, salah satunya adalah transisi demografik yang berpengaruh terhadap terjadinya transisi epidemiologik dalam bidang kesehatan'.

Kondisi ini ditandai dengan jumlah penyakit menular yang mulai menurun di beberapa daerah, dan penyakit tidak menular (jantung koroner, diabetes, kanker, hipertensi, dan lain-lain) yang meningkat. Pola yang sama terjadi pada keadaan gizi, gejala gizi lebih mulai meningkat terutama di daerah perkotaan ${ }^{2}$. Hal ini dapat dijelaskan dari laporan rumah sakit tahun 2000 , tentang gambaran penyebab utama kematian penderita rawat inap di RS yang disebabkan penyakit tidak menular, seperti penyakit stroke 4,8 persen, gagal ginjal 3,7 persen, penyakit jantung 3,7 persen, diabetes mellitus tak bergantung insulin 2,1 persen, dan penyakit jantung iskemik 2,1 persen dari seluruh kematian ${ }^{3}$.

Salah satu penyebab meningkatnya penyakit tidak menular adalah adanya peningkatan pendapatan yang menimbulkan pergeseran pola konsumsi. Melalui kemajuan ilmu pengetahuan dan teknologi, masyarakat dalam waktu relatif singkat telah diperkenalkan dengan selera makanan gaya fast food dan junk food ${ }^{4}$. Pola makan masyarakat di perkotaan bergeser dari pola 
makan tradisional yang mengandung banyak karbohidrat, serat, dan sayuran ke pola makanan barat yang komposisinya terlalu banyak mengandung protein, lemak, gula, garam, tetapi kurang serat ${ }^{5}$. Di samping itu perbaikan ekonomi juga menyebabkan berkurangnya aktifitas fisik masyarakat tertentu. Perubahan pola makan dan aktifitas fisik berakibat semakin banyaknya penduduk golongan tertentu mengalami masalah gizi lebih berupa kegemukan dan obesitas ${ }^{6}$. Penelitian Monica (1994) yang dikutip dari Untoro (2003) menunjukkan bahwa hipertensi didapati pada 19,9 persen usila yang gemuk dan 29,8 persen pada usila dengan obesitas ${ }^{7}$. Sedangkan di negara maju kelompok masyarakat usia 20-45 tahun dengan gizi lebih memiliki risiko relatif sebesar 5,9 kali untuk hipertensi dan 2,9 kali untuk diabetes mellitus dibandingkan dengan kelompok gizi normal'. Kegemukan juga merupakan faktor risiko terjadinya penyakit jantung koroner disamping faktor lainnya, seperti hipertensi, diabetes mellitus, merokok, stress, dan kurang olah raga ${ }^{8}$.

Dari hasil penelitian survei Indeks Massa Tubuh (IMT) di 12 Kotamadya di Indonesia tahun 1995 didapatkan prevalensi gizi lebih sebesar 10,3 persen dan prevalensi obesitas sebesar 12,2 persen. Prevalensi gizi lebih dan obesitas Provinsi Jawa Barat berdasarkan hasil survei tersebut masingmasing adalah 13,3 persen dan 10,3 persen $^{9}$, dan prevalensi gizi lebih ini mengalami peningkatan pada tahun 1999 sebesar 14 persen dan tahun 2000 sebesar 17,4 persen $^{10}$. Sedangkan prevalensi obesitas di Kota Depok Provinsi Jawa Barat tahun 2004 diketahui sebesar 12,5 persen ${ }^{11}$. Untuk mengevaluasi program gizi di Kota Depok dari tahun 2004-2007, khususnya obesitas, maka dilakukan penelitian pemantauan indeks massa tubuh (IMT). Penelitian bertujuan untuk mengetahui faktor-faktor yang berpengaruh terhadap status gizi obesitas orang dewasa di Kota Depok dan bagaimana karakteristiknya.

\section{METODE}

Penelitian dilakukan pada bulan JuniJuli 2007. Rancangan penelitian adalah potong lintang (cross-sectional) dengan populasi laki-laki dan perempuan berumur 18-55 tahun di wilayah Kota Depok Provinsi Jawa Barat. Sedangkan sampel adalah lakilaki dan perempuan berumur 18-55 tahun terpilih. Kriteria sampel yang diambil adalah: laki-laki dan perempuan berumur 18-55 tahun yang berada di wilayah Kota Depok, sampel untuk wanita tidak dalam keadaan hamil dan tidak nifas, tidak cacat fisik dan mental, serta bersedia dijadikan sampel. Sedangkan cara pengambilan sampel dilakukan berdasarkan metode survei cepat, dengan langkah-langkah sebagai berikut: (1) Memilih 20 klaster per kecamatan secara acak, sehingga terpilih 120 klaster (Kota Depok terdiri dari 6 Kecamatan). Unit klaster adalah RW yang dipilih secara acak; (2) Jumlah responden untuk masing-masing kelompok pada tiap klaster dihitung dengan membagi besar sampel masing-masing kelompok dengan jumlah klaster. Berdasarkan perhitungan besar sampel didapatkan 313 sampel ditambah 20 persen untuk menghindari angka drop out, sehingga diperoleh 375 sampel. Jumlah responden tiap klaster 3-4 responden; (3) Memilih responden pada setiap klaster dengan sistim obat nyamuk, di mana titik pusat kluster adalah posyandu di RW terpilih.

Data yang dikumpulkan meliputi: keterangan responden, umur, jenis kelamin, pendidikan, pekerjaan, kebiasaan olahraga, kebiasaan sarapan pagi, kebiasaan makan, tinggi badan, dan berat badan. Kriteria obesitas berdasarkan IMT hasil pengukuran tinggi badan dan berat badan responden, dikatakan obesitas bila IMT>27 dan tidak obesitas bila IMT $\leq 27^{10}$. Kemudian untuk mendapatkan kualitas data yang baik dilakukan pelatihan terhadap petugas pengumpul data, kalibrasi alat ukur (timbangan berat badan dan pengukur tinggi badan (miocrotoice), dan kegiatan supervisi untuk validasi konsistensi data dan validasi pengukuran. Kegiatan validasi pengukuran dilakukan oleh dua orang dalam setiap klaster, dimana masing-masing validator memvalidasi tiga orang pengumpul data. 
Analisis data dilakukan dengan univariat dan bivariat. Analisis univariat untuk melihat gambaran besarnya persentase status gizi obesitas orang dewasa di Kota Depok, dan distribusi frekuensi karakteristik responden. Sedangkan analisis bivariat untuk melihat faktor determinan status gizi obesitas pada orang dewasa digunakan uji Chi-square dengan batas kemaknaan 0,05.
HASIL

\section{Karakteristik responden menurut faktor sosio demografi}

Penelitian ini melibatkan responden sejumlah 366 orang yang memenuhi kriteria sampel. Gambaran karakteristik responden menurut faktor sosio demografi dapat dilihat pada Tabel 1.

Tabel 1

Karakteristik Responden menurut Faktor Sosio Demografi dan Kebiasaan Olahraga di Kota Depok Tahun 2007

\begin{tabular}{|c|c|c|c|}
\hline \multirow{2}{*}{$\begin{array}{c}\text { Faktor } \\
\text { sosio demografi }\end{array}$} & \multicolumn{2}{|c|}{ Kebiasaan Olahraga } & \multirow[b]{2}{*}{$\begin{array}{c}\text { Jumlah } \\
(\mathrm{n}=366)\end{array}$} \\
\hline & $\begin{array}{l}\text { Tidak } \\
(\mathrm{n}=161)\end{array}$ & $\begin{array}{c}Y a \\
(n=205)\end{array}$ & \\
\hline \multicolumn{4}{|l|}{ Umur } \\
\hline$-<25$ tahun & 37,0 & 63,0 & 14,8 \\
\hline - 25-30 tahun & 58,2 & 41,8 & 15,0 \\
\hline - 31-40 tahun & 50,0 & 50,0 & 32,8 \\
\hline$-41-50$ tahun & 34,7 & 65,3 & 26,8 \\
\hline - > 50 tahun & 38,5 & 61,5 & 10,7 \\
\hline \multicolumn{4}{|l|}{ Jenis kelamin } \\
\hline - Laki-laki & 33,0 & 67,0 & 48,1 \\
\hline - Perempuan & 54,2 & 45,8 & 51,9 \\
\hline \multicolumn{4}{|l|}{ Tingkat pendidikan } \\
\hline & 56,8 & 43,2 & 20,2 \\
\hline - SMP & 44,0 & 56,0 & 24,9 \\
\hline - SMA & 38,5 & 61,5 & 44,0 \\
\hline - Perguruan tinggi & 42,5 & 57,5 & 10,9 \\
\hline \multicolumn{4}{|l|}{ Pekerjaan } \\
\hline - PNS dan TNI/POLRI & 23,5 & 76,5 & 4,6 \\
\hline - Karyawan swasta & 29,2 & 70,8 & 19,7 \\
\hline - Pedagang & 53,7 & 46,3 & 14,8 \\
\hline - Tani dan buruh & 50,0 & 50,0 & 11,5 \\
\hline - Tidak bekerja & 42,3 & 57,7 & 21,3 \\
\hline - Ibu rumah tangga & 51,5 & 48,5 & 28,1 \\
\hline Jumlah & 44,0 & 56,0 & 100,0 \\
\hline
\end{tabular}

Menurut kelompok umur responden persentase terbanyak terdapat pada kelompok umur 31-40 tahun, yaitu sebesar 32,8 persen. Kelompok umur 51-55 tahun merupakan kelompok umur terendah di antara kelompok umur yang lain. Sebaran antara responden laki-laki dan perempuan tampak hampir merata. Sedangkan menurut tingkat pendidikan, responden terbanyak adalah dengan pendidikan SMA (44\%) dan responden dengan pendidikan perguruan tinggi (Diploma ke atas) hanya 10,9 persen. 
Selanjutnya menurut jenis pekerjaan, pekerjaan sebagai ibu rumahtangga terlihat cukup dominan di antara kelompok yang lain $(28,1 \%)$, responden yang tidak bekerja (mahasiswa/pelajar, pensiunan, tidak sedang bekerja/ menganggur) sebesar 21,3 persen dan responden yang bekerja sebagai PNS, TNI dan POLRI hanya 4,6 persen.

\section{Karakteristik responden menurut faktor perilaku \\ Kebiasaan olahraga}

Kebiasaan olahraga responden di Kota Depok diketahui sebesar 56 persen dengan lama aktifitas olahraga antara 10 menit sampai 150 menit. Dari Tabel 1 tampak bahwa menurut kelompok umur, kebiasaan olahraga pada rentang umur 25-40 tahun lebih rendah dibandingkan dengan kelompok umur lainnya. Kebiasaan olahraga pada responden laki-laki lebih tinggi daripada perempuan. Menurut tingkat pendidikan dari SD sampai dengan SMA tampak adanya kecenderungan kebiasaan olahraga semakin meningkat. Sedangkan menurut jenis pekerjaan, responden yang bekerja sebagai PNS, TNI/POLRI dan karyawan swasta merupakan responden dengan kebiasaan olahraga cukup baik (di atas $70 \%$ ), namun pada responden yang bekerja sebagai pedagang dan ibu rumahtangga kebiasaan olahraga tampak masih rendah (di bawah $50 \%)$.

Tabel 2

Karakteristik Responden menurut Kebiasaan Sarapan Pagi dan Faktor Sosio Demografi di Kota Depok Tahun 2007

\begin{tabular}{|c|c|c|}
\hline \multirow{2}{*}{$\begin{array}{c}\text { Faktor } \\
\text { sosio demografi }\end{array}$} & \multicolumn{2}{|c|}{ Kebiasaan sarapan pagi } \\
\hline & $\begin{array}{c}\text { Tidak } \\
(\mathrm{n}=75)\end{array}$ & $\begin{array}{c}\mathrm{Ya} \\
(\mathrm{n}=291)\end{array}$ \\
\hline & $\%$ & $\%$ \\
\hline Umur & & \\
\hline$-<25$ tahun & 29,6 & 70,4 \\
\hline - 25-30 tahun & 16,4 & 83,6 \\
\hline - 31-40 tahun & 22,5 & 77,5 \\
\hline - 41-50 tahun & 17,3 & 82,7 \\
\hline - > 50 tahun & 15,4 & 84,6 \\
\hline Jenis kelamin & & \\
\hline - Laki-laki & 22,2 & 77,8 \\
\hline - Perempuan & 18,9 & 81,1 \\
\hline Tingkat pendidikan & & \\
\hline - SD & 27,0 & 73,0 \\
\hline - SMP & 20,9 & 79,1 \\
\hline - SMA & 18,0 & 82,0 \\
\hline - Perguruan tinggi & 17,5 & 82,5 \\
\hline Pekerjaan & & \\
\hline - PNS dan TNI/POLRI & 5,9 & 94,1 \\
\hline - Karyawan swasta & 22,2 & 77,8 \\
\hline - Pedagang & 29,6 & 70,4 \\
\hline - Tani/buruh & 23,8 & 76,2 \\
\hline - Tidak bekerja & 21,8 & 78,2 \\
\hline - Ibu rumah tangga & 14,6 & 85,4 \\
\hline Jumlah & 20,5 & 79,5 \\
\hline
\end{tabular}




\section{Kebiasaan sarapan pagi}

Kebiasaan sarapan pagi responden diketahui sebesar 79,5 persen. Menu sarapan pagi yang sering dikonsumsi adalah nasi lengkap (nasi+lauk+sayur), nasi uduk, nasi goreng, bubur ayam, dan lontong sayur. Responden yang mengonsumsi sarapan pagi dengan menu tidak lengkap, seperti: roti dengan susu, kue/ makanan gorengan dengan kopi, sebesar 15,3 persen. Secara rinci gambaran kebiasaan sarapan pagi responden dijelaskan pada Tabel 2. Menurut kelompok umur tampak bahwa kebiasaan sarapan pagi sudah cukup baik (di atas $70 \%$ ). Pada responden perempuan kebiasaan sarapan pagi sedikit lebih tinggi daripada responden laki-laki. Sedangkan menurut tingkat pendidikan tampak adanya kecenderungan kebiasaan sarapan pagi lebih baik dengan semakin meningkatnya tingkat pendidikan. Selanjutnya menurut pekerjaan, kebiasaan sarapan pagi tampak lebih tinggi pada responden yang bekerja sebagai PNS, TNI/POLRI dan ibu rumahtangga dibandingkan dengan kelompok lain.

\section{Kebiasaan makan}

Dari Tabel 3 diketahui bahwa responden yang sering mengonsumsi sumber protein hewani dan protein nabati (lebih dari 3 kali seminggu) terlihat cukup tinggi, yaitu sebesar 88,5 persen. Sedangkan kebiasaan responden yang sering mengonsumsi makanan berlemak dan makanan gorengan masing-masing sebesar 52,5 persen dan 59,3 persen. Selanjutnya diketahui bahwa sebagian besar responden yang sering mengonsumsi makanan trendi dan minuman softdrink, yaitu masing-masing sebesar 37,7 persen dan 40,7 persen.

Tabel 3

Karakteristik Responden menurut Kebiasaan Makan di Kota Depok Tahun 2007

\begin{tabular}{|c|c|c|}
\hline \multicolumn{2}{|c|}{ Kebiasaan makan } & Jumlah (n=366) \\
\hline Sumber protein hewani & $\begin{array}{l}\text { - Sering } \\
\text { - Jarang }\end{array}$ & $\begin{array}{r}\% \\
88,5 \\
11,5\end{array}$ \\
\hline Sumber protein nabati & $\begin{array}{l}\text { - Sering } \\
\text { - Jarang }\end{array}$ & $\begin{array}{r}90,2 \\
9,8\end{array}$ \\
\hline Makanan berlemak & $\begin{array}{l}\text { - Sering } \\
\text { - Jarang }\end{array}$ & $\begin{array}{l}52,5 \\
47,5\end{array}$ \\
\hline Makanan gorengan & $\begin{array}{l}\text { - Sering } \\
\text { - Jarang }\end{array}$ & $\begin{array}{l}59,3 \\
40,7\end{array}$ \\
\hline Makanan trendi & $\begin{array}{l}\text { - Sering } \\
\square \text { Jarang }\end{array}$ & $\begin{array}{l}37,7 \\
62,3\end{array}$ \\
\hline Minuman softdrink & $\begin{array}{l}\text { - Sering } \\
\text { - Jarang }\end{array}$ & $\begin{array}{l}40,7 \\
59,3\end{array}$ \\
\hline
\end{tabular}

\section{Kebiasaan jajan dan makanan kesukaan/kegemaran}

Kebiasaan jajan responden diketahui sebesar 67,8 persen (248 dari 366). Makanan jajan yang sering dikonsumsi adalah makanan ringan (chiki, keripik, kerupuk), permen, dan makanan gorengan. Selanjutnya menurut makanan kesukaan/ kegemaran responden diketahui bahwa sebagian besar responden menyukai 
makanan gorengan (pisang goreng, tempe/ tahu goreng, bakwan, dan lain-lain), yaitu sebesar 86,1 persen. Responden yang menyukai makanan berlemak hanya 29,2 persen, sedangkan responden yang menyukai makanan manis sebesar 59 persen (Tabel 4).

Tabel 4

Karakteristik Responden menurut Makanan Kesukaan/ Kegemaran di Kota Depok Tahun 2007

\begin{tabular}{llr}
\hline \multicolumn{2}{c}{ Kesukaan/ kegemaran makan } & Jumlah $(\mathrm{n}=366)$ \\
\hline \multirow{3}{*}{ Makanan gorengan } & 口 Ya & 86,1 \\
& 口 Tidak & 13,9 \\
Makanan berlemak & 口 Ya & 29,2 \\
Makanan manis & 口 Tidak & 70,8 \\
& व Ya & 59,0 \\
& व Tidak & 41,0 \\
\hline
\end{tabular}

\section{Status gizi obesitas}

Persentase status gizi obesitas pada orang dewasa di Kota Depok (IMT>27,0) ditemukan sebesar 16,4 persen (60 dari 366 responden). Rata-rata IMT diketahui sebesar $23,26 \mathrm{~kg} / \mathrm{m}^{2}$ dengan standar deviasi $3,89 \mathrm{~kg} /$ $\mathrm{m}^{2}$, IMT minimum $14,37 \mathrm{~kg} / \mathrm{m}^{2}$ dan maksimum $39,17 \mathrm{~kg} / \mathrm{m}^{2}$.

\section{Status gizi obesitas menurut faktor sosio demografi}

Menurut kelompok umur responden, persentase tertinggi obesitas terdapat pada kelompok umur 31-40 tahun, yaitu sebesar 21,7 persen dan persentase obesitas terendah terdapat pada kelompok umur kurang dari 25 tahun (5,6\%). Dari Tabel 5 tampak adanya kecenderungan peningkatan kejadian obesitas sampai dengan umur 50 tahun. Dari hasil analisis didapatkan nilai $p=$ 0,044 , sehingga dapat disimpulkan adanya pengaruh kelompok umur terhadap status obesitas. Sedangkan persentase obesitas pada perempuan diketahui sebesar 21,6 persen dua kali lipat persentase obesitas pada laki-laki $(10,8 \%)$. Dari hasil analisis diketahui adanya pengaruh jenis kelamin terhadap status obesitas $(p=0,008)$. Hasil analisis lanjut mendapatkan nilai $\mathrm{OR}=2,274$, artinya responden perempuan mempunyai risiko menjadi obesitas sebesar 2,274 kali dibandingkan dengan responden laki-laki.

Dari tingkat pendidikan responden, tampak bahwa persentase obesitas tertinggi terdapat pada responden dengan pendidikan SMP, yaitu sebesar 23,1 persen, dan persentase terendah terdapat pada responden dengan pendidikan perguruan tinggi (10\%). Hasil analisis tidak menunjukkan adanya pengaruh antara tingkat pendidikan terhadap status obesitas $(p=0,197)$.

Kemudian dilihat dari jenis pekerjaan responden diketahui bahwa persentase obesitas tertinggi terdapat pada responden yang bekerja sebagai PNS, TNI/POLRI, yaitu sebesar 29,4 persen, dan persentase terendah terdapat pada responden yang bekerja sebagai petani/ buruh, yaitu sebesar 4,8 persen. Dari hasil analisis tidak menunjukkan adanya pengaruh antara jenis pekerjaan dengan status obesitas $(p=0,090)$. 
Tabel 5

Karakteristik Responden menurut Status Gizi dan Faktor Sosio Demografi di Kota Depok Tahun 2007

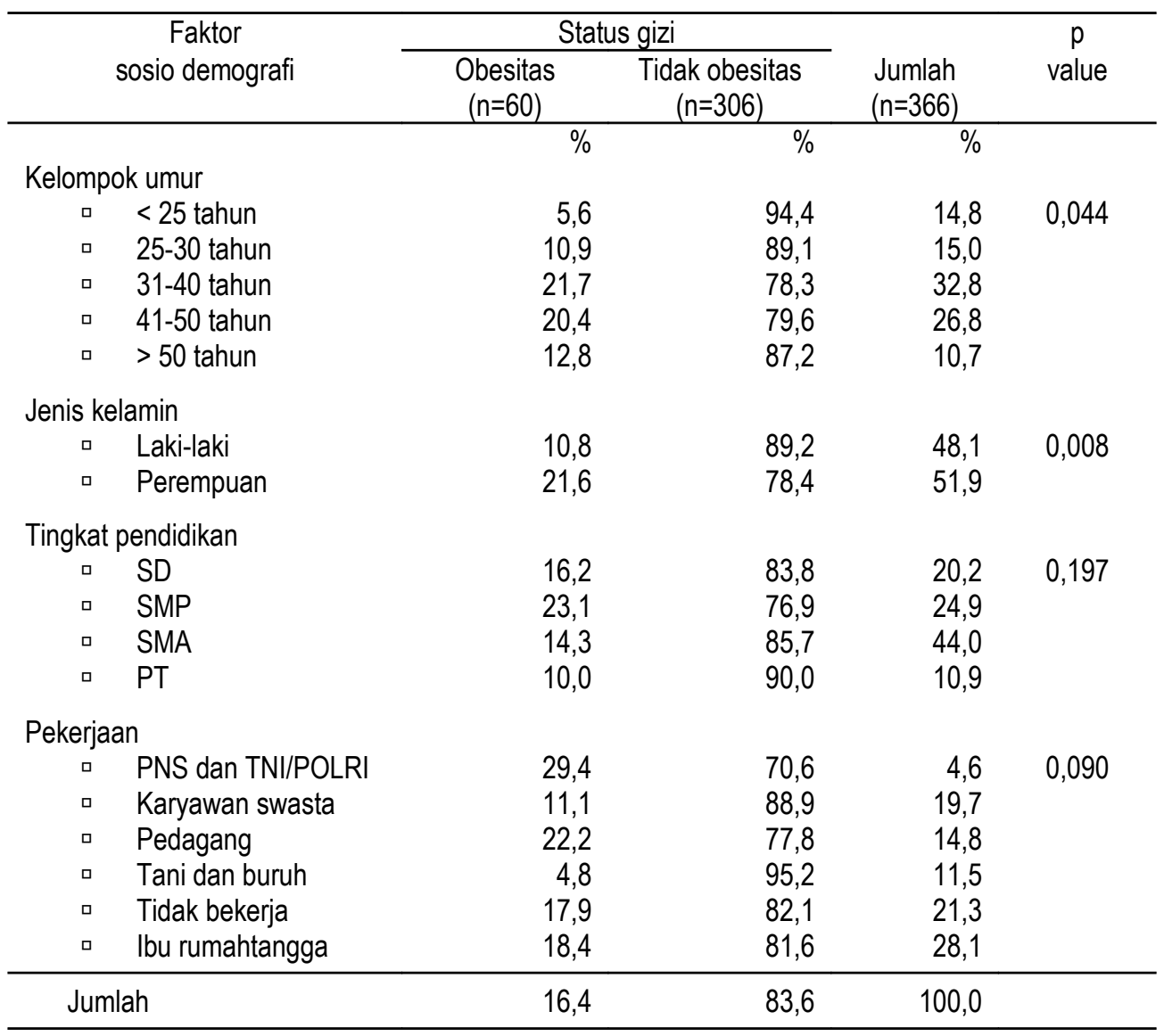

\section{Status gizi obesitas menurut faktor} perilaku

Faktor determinan status gizi obesitas menurut faktor perilaku dijelaskan pada Tabel 6. Faktor perilaku meliputi kebiasaan olahraga, kebiasaan makan (pola makan), kebiasaan sarapan pagi, dan kebiasaan jajan. Dilihat dari faktor perilaku tampak adanya kecenderungan peningkatan persentase obesitas pada responden yang tidak berolahraga $(18 \%)$, responden dengan pola makan sehari $>=3$ kali $(16,9 \%)$, responden yang sarapan pagi dengan menu tidak lengkap $(17,9 \%)$, dan responden yang mengonsumsi makanan jajanan/ jajan $(17,2 \%)$, walaupun secara statistik tidak menunjukkan adanya pengaruh yang bermakna dengan status gizi obesitas ( $p>$ $0,05)$. 
Tabel 6

Distribusi Responden menurut Status Gizi dan Faktor Perilaku di Kota Depok Tahun 2007

\begin{tabular}{|c|c|c|c|c|}
\hline \multirow[b]{2}{*}{ Faktor perilaku } & \multicolumn{2}{|c|}{ Status gizi } & \multirow[b]{2}{*}{$\begin{array}{l}\text { Jumlah } \\
(n=366)\end{array}$} & \multirow{2}{*}{$\begin{array}{c}\mathrm{p} \\
\text { value }\end{array}$} \\
\hline & $\begin{array}{c}\begin{array}{c}\text { Obesitas } \\
(n=60)\end{array} \\
\end{array}$ & $\begin{array}{c}\text { Tidak obesitas } \\
(n=306)\end{array}$ & & \\
\hline Kebiasaan olahraga & $\%$ & $\%$ & $\%$ & \\
\hline $\begin{array}{l}\text { - Ya } \\
\text { - Tidak }\end{array}$ & $\begin{array}{l}15,1 \\
18,0\end{array}$ & $\begin{array}{l}84,9 \\
82,0\end{array}$ & $\begin{array}{l}56,0 \\
44,0\end{array}$ & 0,549 \\
\hline Kebiasaan makan & & & & \\
\hline $\begin{array}{l}\text { - } 2 \text { kali sehari } \\
\text { - >= } 3 \text { kali sehari }\end{array}$ & $\begin{array}{l}15,4 \\
16,9\end{array}$ & $\begin{array}{l}84,6 \\
83,1\end{array}$ & $\begin{array}{l}32,0 \\
68,0\end{array}$ & 0,837 \\
\hline $\begin{array}{l}\text { Kebiasaan sarapan pagi } \\
\text { - Sarapan (menu lengkap) } \\
\text { - Sarapan (menu tdk lengkap) } \\
\text { - Tidak sarapan }\end{array}$ & $\begin{array}{l}17,0 \\
17,9 \\
13,3\end{array}$ & $\begin{array}{l}83,0 \\
82,1 \\
86,7\end{array}$ & $\begin{array}{l}64,2 \\
15,3 \\
20,5\end{array}$ & 0,716 \\
\hline $\begin{array}{l}\text { Kebiasaan jajan } \\
\square \text { Ya } \\
\square \text { Tidak }\end{array}$ & $\begin{array}{l}19,0 \\
11,0\end{array}$ & $\begin{array}{l}81,0 \\
89,0\end{array}$ & $\begin{array}{l}67,8 \\
32,2\end{array}$ & 0,077 \\
\hline Jumlah & 16,4 & 83,6 & 100,0 & \\
\hline
\end{tabular}

Selanjutnya diketahui bahwa persentase status obesitas lebih tinggi pada responden yang mempunyai kebiasaan jajan, terutama pada responden yang tidak berolahraga, yaitu sebesar 20,5 persen. Persentase status gizi obesitas juga cenderung lebih tinggi pada responden dengan kebiasaan makan 2 kali sehari, tetapi mempunyai kebiasaan jajan $(20,3 \%)$ maupun pada responden dengan kebiasaan makan $\geq 3$ kali sehari $(18,4 \%)$. Begitu pula dengan kebiasaan sarapan pagi, persentase obesitas lebih tinggi pada responden yang mempunyai kebiasaan jajan, baik pada responden yang sarapan pagi dengan menu lengkap $(19,1 \%)$, maupun pada responden yang sarapan pagi dengan menu tidak lengkap $(21,4 \%)$. Peranan kebiasaan jajan lebih tampak lagi pada penggabungan ketiga faktor tersebut. Persentase obesitas lebih tinggi pada responden dengan kebiasaan jajan baik pada responden yang sarapan pagi, tidak sarapan pagi, makan sehari 2 kali, dan makan sehari $\geq 3$ kali (Tabel 7). 
Tabel 7

Persentase Status Gizi Orang Dewasa menurut Kebiasaan Olahraga, Kebiasaan Makan, Kebiasaan Sarapan Pagi, dan Kebiasaan Jajan di Kota Depok Tahun 2007

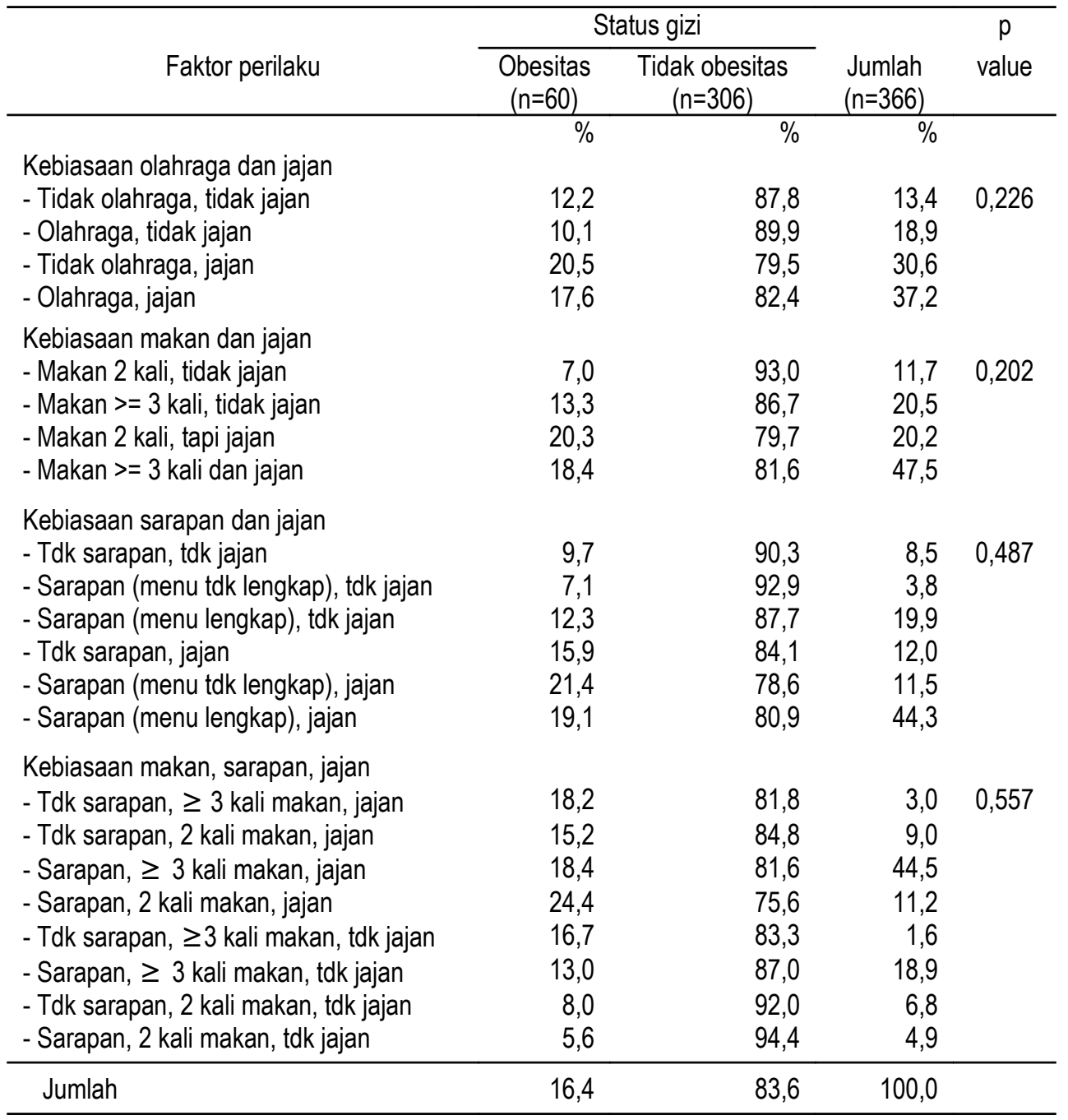

Persentase status obesitas tampak lebih tinggi pada responden yang sering mengonsumsi makanan sumber protein hewani $(17 \%)$, sumber protein nabati $(17 \%)$, makanan berlemak $(17,7 \%)$, makanan gorengan $(20,7 \%)$, makanan trendi $(18,8 \%)$, dan minuman softdrink (18,1\%). Dari hasil analisis menunjukkan adanya pengaruh antara makanan gorengan dengan status obesitas $(p=0,010)$. Selanjutnya diperoleh nilai $O R=2,337(1,249-4,373)$, artinya responden yang sering mengonsumsi makanan gorengan berisiko obesitas sebesar 2,337 kali dibandingkan dengan responden yang jarang mengonsumsi makanan gorengan (Tabel 8). 
Tabel 8

Distribusi Responden menurut Kebiasaan Makan dan Status Gizi di Kota Depok Tahun 2007

\begin{tabular}{|c|c|c|c|c|}
\hline \multirow[b]{2}{*}{ Kebiasaan makan } & \multicolumn{2}{|c|}{ Status gizi } & \multirow[b]{2}{*}{$\begin{array}{l}\text { Jumlah } \\
(n=366)\end{array}$} & \multirow[b]{2}{*}{$\begin{array}{c}p \\
\text { value }\end{array}$} \\
\hline & $\begin{array}{c}\text { Obesitas } \\
(n=60)\end{array}$ & $\begin{array}{c}\text { Tidak obesitas } \\
(n=306)\end{array}$ & & \\
\hline Sumber protein hewan & $\%$ & $\%$ & & \\
\hline - Sering & 17,0 & 83,0 & 88,5 & 0,539 \\
\hline & & & & \\
\hline \multicolumn{5}{|l|}{ Sumber protein nabati } \\
\hline 口 Sering & 17,0 & 83,0 & 90,2 & 0,506 \\
\hline - Jarang & 11,1 & 88,9 & 9,8 & \\
\hline \multicolumn{5}{|l|}{ Makanan berlemak } \\
\hline - Sering & 17,7 & 82,3 & 52,5 & 0,567 \\
\hline - Jarang & 14,9 & 85,1 & 47,5 & \\
\hline \multicolumn{5}{|l|}{ Makanan gorengan ${ }^{*}$} \\
\hline - Sering & 20,7 & 79,3 & 59,3 & 0,010 \\
\hline - Jarang & 10,1 & 89,9 & 40,7 & \\
\hline \multicolumn{5}{|l|}{ Makanan trendi } \\
\hline 口 Sering & 18,8 & 81,2 & 37,7 & 0,402 \\
\hline 口 Jarang & 14,9 & 85,1 & 62,3 & \\
\hline \multicolumn{5}{|l|}{ Minuman softdrink } \\
\hline - Sering & 18,1 & 81,9 & 40,7 & 0,551 \\
\hline - Jarang & 15,2 & 84,8 & 59,3 & \\
\hline Jumlah & 16,4 & 83,6 & 100,0 & \\
\hline
\end{tabular}

Catatan *): $p<0,05$

Sedangkan menurut makanan kesukaan/kegemaran responden, diketahui bahwa persentase obesitas lebih tinggi pada responden yang menyukai makanan gorengan, makanan berlemak, dan makanan manis. Dari hasil analisis menunjukkan adanya pengaruh yang signifikan antara responden yang menyukai makanan gorengan, makanan berlemak, dan makanan manis dengan kejadian obesitas $(p<0,05)$ (Tabel 9). 
Tabel 9

Distribusi Responden menurut Kesukaan Makan dan Status Gizi di Kota Depok Tahun 2007

\begin{tabular}{|c|c|c|c|c|}
\hline \multirow[b]{2}{*}{ Kesukaan makan } & \multicolumn{2}{|c|}{ Status gizi } & \multirow[b]{2}{*}{$\begin{array}{c}\text { OR } \\
(95 \% \mathrm{Cl})\end{array}$} & \multirow[b]{2}{*}{$\begin{array}{c}p \\
\text { value }\end{array}$} \\
\hline & $\begin{array}{c}\text { Obesitas } \\
(n=50)\end{array}$ & $\begin{array}{l}\text { Tidak obesitas } \\
\quad(n=349)\end{array}$ & & \\
\hline & $\%$ & $\%$ & & \\
\hline \multicolumn{5}{|l|}{ Makanan gorengan } \\
\hline - $\mathrm{Ya}$ & 18,1 & 81,9 & 3,535 & 0,048 \\
\hline 口 Tidak & 5,9 & 94,1 & $(1,063-11,750)$ & \\
\hline \multicolumn{5}{|l|}{ Makanan berlemak } \\
\hline - $\mathrm{Ya}$ & 23,4 & 76,6 & 1,951 & 0,031 \\
\hline 口 Tidak & 13,5 & 86,5 & $(1,101-3,458)$ & \\
\hline \multicolumn{5}{|l|}{ Makanan manis } \\
\hline - $\mathrm{Ya}$ & 20,4 & 79,6 & 2,142 & 0,020 \\
\hline 口 Tidak & 10,7 & 89,3 & $(1,158-3,963)$ & \\
\hline Jumlah & 16,4 & 83,6 & & \\
\hline
\end{tabular}

\section{BAHASAN}

Persentase status gizi obesitas pada orang dewasa di Kota Depok (IMT>27,0) ditemukan sebesar 16,4 persen (60 dari 366 responden) lebih tinggi dari penelitian sebelumnya, yaitu sebesar 12,5 persen ${ }^{11}$. Demikian juga jika dibandingkan penelitian dengan skala nasional pada tahun $1995 \mathrm{di}$ 12 Kotamadya di Indonesia, yaitu sebesar 12,2 persen $^{9}$.

Adanya kecenderungan peningkatan status gizi obesitas, khususnya di daerah perkotaan harus menjadi perhatian khusus bagi Dinas Kesehatan Kota serta instansi pemerintah lain, dan organisasi masyarakat. Program pencegahan dini merupakan langkah yang tepat untuk memperlambat peningkatan status gizi obesitas. Kampanye hidup bersih dan sehat, mengkonsumsi makanan sehat, memasyarakatkan kembali makanan tradisional kepada anak-anak sekolah terutama di perkotaan bisa menjadi program pilihan. Hal ini mengingat persentase obesitas pada murid sekolah di perkotaan juga menunjukkan peningkatan. Penelitian terhadap murid SD antara umur 912 tahun di Kota Bogor tahun 2001 menunjukkan persentase gizi lebih sebesar 7,7 persen $^{12}$. Penelitian terhadap anak usia sekolah dasar di SD favorit di Kota Bandung pada tahun yang sama menunjukkan prevalensi gizi lebih sebesar 16 persen ${ }^{13}$. Selanjutnya data Survei Kesehatan Rumah Tangga (SKRT) tahun 2004 menunjukkan bahwa prevalensi gizi lebih pada kelompok anak usia 5-12 tahun sebesar 8,5 persen ${ }^{14}$. Menurut WHO (2000) bahwa kejadian kegemukan pada usia dewasa dimulai sejak masa kanak-kanak, yaitu 36 persen berawal sejak umur 3-6 tahun dan 55 persen berawal sejak umur 6-10 tahun ${ }^{15}$.

Menurut kelompok umur, persentase status gizi obesitas tertinggi terdapat pada kelompok umur 31-40 tahun, yaitu sebesar 21,7 persen. Terdapat kecenderungan peningkatan kejadian obesitas sampai dengan umur 50 tahun. Sedangkan pada penelitian sebelumnya persentase status gizi obesitas tertinggi terdapat pada kelompok umur di atas 50 tahun, yaitu sebesar 19,6 persen ${ }^{11}$. Terjadinya pergeseran kejadian obesitas pada kelompok umur lebih muda dapat menjadi salah satu faktor pemicu terhadap peningkatan penyakit degeneratif pada kelompok usia di atas 30 tahun. Dari hasil analisis dapat disimpulkan adanya pengaruh kelompok umur terhadap status gizi obesitas $(p=0,044)$. 
Dari data jenis kelamin, persentase obesitas pada perempuan diketahui sebesar 21,6 persen lebih tinggi dibandingkan persentase obesitas pada laki-laki $(10,8 \%)$. Hasil ini tidak jauh berbeda dengan penelitian sebelumnya yang menunjukkan persentase obesitas pada perempuan lebih tinggi dibandingkan pada laki-laki ${ }^{11}$. Dari hasil analisis diketahui adanya pengaruh jenis kelamin terhadap status obesitas ( $p=$ 0,008 ). Hasil analisis juga mendapatkan nilai $\mathrm{OR}=2,274$, artinya responden perempuan mempunyai risiko menjadi obesitas sebesar 2,274 kali dibandingkan dengan responden laki-laki. Hal ini dapat dijelaskan bahwa kebiasaan olahraga pada perempuan hanya 45,8 persen lebih rendah daripada aktifitas olahraga yang dilakukan laki-laki (67\%).

Dari tingkat pendidikan responden tidak menunjukkan adanya pengaruh tingkat pendidikan terhadap status gizi obesitas. Walaupun demikian tampak adanya kecenderungan penurunan kejadian obesitas dengan semakin meningkatnya tingkat pendidikan responden. Hasil ini tidak jauh berbeda dengan penelitian sebelumnya yang mendapatkan persentase obesitas tertinggi pada responden dengan tingkat pendidikan SMP, yaitu sebesar 18 persen dan terendah pada responden dengan tingkat pendidikan perguruan tinggi $(4 \%)^{11}$. Begitu juga dengan survei lain yang mendapatkan bahwa overweight ditemukan paling rendah pada responden yang berpendidikan perguruan tinggi yakni 12,1persen pada bapak dan 13,3 persen pada ibu ${ }^{16}$.

Persentase status gizi obesitas menurut jenis pekerjaan terlihat cukup bervariasi. Persentase obesitas tertinggi terdapat pada responden yang bekerja sebagai PNS, TNI/POLRI, yaitu sebesar 29,4 persen, kemudian pada pedagang $(22,2 \%)$, ibu rumah tangga $(18,4 \%)$, dan persentase terendah terdapat pada responden yang bekerja sebagai petani/ buruh, yaitu sebesar 4,8 persen. Dari hasil analisis tidak menunjukkan adanya pengaruh antara jenis pekerjaan dengan status obesitas ( $p=$ $0,090)$. Hal ini berbeda dengan penelitian sebelumnya yang menunjukkan adanya pengaruh antara jenis pekerjaan dengan status gizi obesitas. Salah satu sebabnya adalah perbedaan pengelompokkan pekerjaan responden dengan penelitian sebelumnya. Pada penelitian tahun 2004 ibu rumah tangga termasuk dalam kelompok tidak bekerja, sedangkan pada penelitian tahun 2007 ibu rumah tangga dikelompokkan dalam jenis pekerjaan tersendiri. Namun demikian pola kejadian obesitas menurut jenis pekerjaan terlihat tidak jauh berbeda. Responden dengan pekerjaan sebagai PNS, TNI/POLRI, pedagang, dan ibu rumahtangga merupakan kelompok responden yang mempunyai risiko terjadi obesitas lebih tinggi dibandingkan kelompok lain.

Jika dilihat dari kebiasaan olahraga yang dilakukan sebetulnya kelompok responden yang bekerja sebagai PNS, TNI/POLRI (76,5\%) lebih baik dibandingkan dengan kelompok responden yang bekerja sebagai pedagang $(46,3 \%)$ dan ibu rumahtangga $(48,5 \%)$. Hal ini dapat dijelaskan dengan pola pekerjaan sebagai PNS, TNI/POLRI yang sering banyak duduk, lebih santai, kemungkinan lebih mapan dibandingkan dengan kelompok pekerjaan lain, responden dengan pekerjaan sebagai PNS, TNI/POLRI lebih sering untuk menikmati makanan tambahan, baik makanan kecil ataupun makanan lengkap pada waktu rapat di kantor maupun di luar kantor. Demikian juga dengan responden yang bekerja sebagai pedagang dan ibu rumahtangga, aktifitas olahraga yang jarang dilakukan, dan kebiasaan ibu rumahtangga yang bekerja di sekitar rumah, cenderung lebih santai, lebih banyak menonton televisi, cenderung mengonsumsi makanan lebih banyak. Kondisi ini tentunya dapat memicu terjadinya obesitas.

Hasil analisis belum menunjukkan pengaruh yang signifikan antara kebiasaan olahraga, kebiasaan makan (pola makan), kebiasaan sarapan pagi, dan kebiasaan jajan dengan status gizi obesitas pada orang dewasa. Namun demikian sudah terlihat kecenderungan peningkatan persentase status gizi obesitas pada responden yang tidak berolahraga, responden dengan kebiasaan makan $\geq 3$ kali, responden yang selalu sarapan pagi dengan menu tidak 
lengkap, dan responden yang memiliki kebiasaan jajan. Secara teori sarapan pagi merupakan kegiatan yang perlu dilakukan. Pada umumnya orang yang tidak sarapan pagi atau sarapan pagi dengan menu tidak lengkap akan menurun produktivitas kerjanya. Sebagian orang mengganti sarapan pagi atau kekurangan sarapan pagi dengan makan siang yang berlebihan atau memakan makanan kecil yang tinggi lemak dan kalori dalam jumlah yang relatif banyak (makanan cemilan, makanan gorengan, makanan berlemak). Dengan demikian kalau dihitung jumlah kalori yang masuk ke dalam tubuh lebih banyak jika dibandingkan melakukan sarapan pagi ${ }^{17}$.

Kebiasaan jajan terlihat cukup besar pengaruhnya untuk menjadi obesitas baik pada responden yang selalu melakukan aktifitas olahraga maupun responden yang tidak melakukan olahraga. Persentase status gizi obesitas juga tampak lebih tinggi pada responden dengan kebiasaan makan 2 kali sehari maupun pada responden dengan kebiasaan makan $\geq 3$ kali sehari. Begitu pula dengan kebiasaan sarapan pagi, persentase obesitas lebih tinggi pada responden yang mempunyai kebiasaan jajan, baik pada responden yang sarapan pagi dengan menu lengkap maupun pada responden sarapan pagi dengan menu tidak lengkap.

Persentase status gizi obesitas juga tampak lebih tinggi pada responden yang sering mengonsumsi makanan sumber protein hewani, sumber protein nabati, makanan berlemak, makanan gorengan, makanan trendi, dan minuman softdrink. Jika dibandingkan dengan penelitian tahun 2004, terdapat peningkatan konsumsi terhadap makanan sumber protein, yaitu dari 15,3 persen menjadi 17 persen, dan peningkatan terhadap konsumsi makanan berlemak, yaitu dari 7,7 persen menjadi 17,7 persen. Dari hasil analisis menunjukkan adanya pengaruh antara makanan gorengan dengan status obesitas $(p=0,010)$. Responden yang sering mengonsumsi makanan gorengan berisiko menjadi obesitas sebesar 2,337 kali dibandingkan dengan responden yang jarang mengonsumsi makanan gorengan.
Selanjutnya hasil analisis menunjukkan adanya pengaruh yang signifikan antara responden yang menyukai makanan gorengan, makanan berlemak, dan makanan manis dengan status gizi obesitas $(p<0,05)$. Persentase obesitas lebih tinggi pada responden yang menyukai makanan gorengan, makanan berlemak, dan makanan manis. Sebagaimana diketahui bahwa makanan gorengan, makanan berlemak, dan makanan manis mengandung kalori lebih tinggi. Kelebihan energi akan disimpan dalam tubuh sebagai lemak. Menurut angka kecukupan gizi yang dianjurkan, kebutuhan kalori golongan umur 20-59 pada laki-laki dengan berat badan $62 \mathrm{~kg}$ dan aktivitas sedang adalah $3.000 \mathrm{Kkal}$, sedangkan pada perempuan dengan golongan umur 20-59, berat badan $54 \mathrm{~kg}$ dan aktivitas sedang adalah $2.250 \mathrm{Kkal}^{18}$.

\section{KESIMPULAN}

1. Persentase status gizi obesitas pada orang dewasa (18-55 tahun) tahun 2007 di Kota Depok sebesar 16,4 persen lebih tinggi dari hasil penelitian tahun 2004 (12,5\%).

2. Hasil analisis bivariat menunjukkan bahwa faktor-faktor yang berpengaruh terhadap status gizi obesitas meliputi: umur, jenis kelamin, kebiasaan makan makanan gorengan, dan makanan kesukaan/ kegemaran (makanan gorengan, makanan berlemak, dan makanan manis).

\section{RUJUKAN}

1. Satoto, Sri Karjati, Budhi Darmojo, Askandar Tjokroprawiro, dan Benny A. Kodyat, Kegemukan, Obesitas, dan Penyakit Degeneratif: Epidemiologi dan Strategi Penanggulangan, Makalah pada Widya Karya Nasional Pangan dan Gizi VI, Jakarta, LIPI,1998.

2. Atmawikarta, Arum, Perencanaan Kebijakan Nasional Bidang Gizi untuk Kelompok Dewasa dan Lanjut Usia di 
Indonesia, Makalah pada Seminar Gizi dan Penyakit Kardiovaskuler pada Kelompok Dewasa dan Usia Lanjut di Indonesia, Depok, 5 Juli 2003.

3. Departemen Kesehatan RI, Profil Kesehatan Indonesia 2002, Jakarta; Depkes, 2004.

4. Soekirman, Menghadapi Masalah Gizi Ganda Dalam Pembangunan Jangka Panjang Kedua: Agenda Repelita VI, Risalah Widya Karya Nasional Pangan dan Gizi V. Jakarta; LIPI, 1994.

5. Suyono, Slamet dan Djauzi S., Penyakit Degeneratif dan Gizi Lebih, Risalah Widya Karya Nasional Pangan dan Gizi V, Jakarta: LIPI, 1994.

6. Almatsier, Sunita, Prinsip Dasar IImu Gizi, Jakarta; Gramedia Pustaka Utama, 2001.

7. Untoro, Rachmi, Kebijakan Program Gizi pada Kelompok Dewasa dan Usia Lanjut di Indonesia, Seminar Gizi dan Penyakit Kardiovaskuler pada Kelompok Dewasa dan Usia Lanjut di Indonesia, Depok, 5 Juli 2003.

8. Supari, Fadillah, Penyakit Jantung Koroner dan Pencegahannya, Seminar Gizi dan Kesehatan Populer, Bogor, 12 Juni 2003.

9. Kodyat, dkk., Survei Indek Massa Tubuh (IMT) di 12 Kotamadya, Indonesia, Gizi Indonesia. 1996, Vol.XXI, hal. 52-61.

10. Departemen Kesehatan RI, Petunjuk Teknis Pemantauan Status Gizi Orang Dewasa dengan Indeks Massa Tubuh (IMT), Jakarta; Depkes, 2003.
11. Sudikno dan Sandjaja, Status Obesitas Orang Dewasa menurut Faktor Sosio Demografi dan Perilaku: Studi Kasus di Kota Depok, Penelitian Gizi dan Makanan. 2005, Vol. 28 No. 2, hal.7482.

12. Hermina dan Abas Basuni Jahari, Ukuran Lingkar Pergelangan Tangan sebagai Indikator Kegemukan pada Anak Usia Sekolah Dasar di Kota Bogor Jawa Barat, Gizi Indonesia. 2007, Vol. 30 No. 2, hal. 137-142.

13. Hermina, dkk., Pengembangan Intervensi Pendidikan Gizi untuk Anak Usia Sekolah Dasar pada Keluarga Menengah di Perkotaan (Laporan Penelitian Risbinkes), Jakarta: Badan Penelitian dan Pengembangan Depkes RI, 2002.

14. Badan Penelitian dan Pengembangan Depkes RI, Survei Kesehatan Rumah Tangga tahun 2004, Jakarta; Balitbangkes. 2005.

15. Inou, S. and Zilmet, P., The AsiaPacific Perspective: Redefining Obesity and its Treatment, Geneva: WHO, 2000.

16. Budiman, Hendra dan Surjadi, Charles, Penelitian Obesitas pada Orang Dewasa di Perkampungan Kumuh Jakarta, Jurnal Epidemiologi Indonesia. 1997, Vol.I Edisi 1.

17. Purwati, Susi, dkk., Perencanaan Menu untuk Penderita Kegemukan, Jakarta: Penebar Swadaya, 2002.

18. Muhilal, dkk., Angka Kecukupan Gizi Yang Dianjurkan, Gizi Indonesia. 1993, Vol.XVIII, No.1-2. 